\title{
MAKNA PENCERAHAN DALAM ZEN BUDDHISME
}

\author{
Oleh: \\ Firman Adi Juwono \\ Universitas Gadjah Mada, Yogyakarta \\ firman.aj@gmail.com
}

\begin{abstract}
Within the Zen Buddhism, there is satori, a term used to designate the essence of the Zen's teachings. According to the Japanese, the term satori is taken as the teaching concerned about illumination or enlightenment. The enlightenment is the achievement as what spiritually discerned by the Gautama Buddhist. It is an experience that implies meaning beyond the common sense where words are not enough to explain. The human being that afford to climb until this satori state after particular Zen's exercises may only experience some inner changes. Hence, he/ she would view the world and the surrounding in a wider horizon, as it is, and able to feel like he has going through a rebirth with a new personality.
\end{abstract}

\begin{abstract}
Abstrak
Dalam Zen Buddhisme dikenal istilah satori, yang dianggap sebagai esensi zen. Dalam pengertian orang Jepang, satori diipahami pula sebagai ajaran tentang pencerahan atau penerangan. Pencapaian pencerahan adalah pencapaian seperti yang dilalui oleh Sang Buddha Gautama. Pengalaman mencapai pencerahan dipercaya sebagai hal yang tidak dapat diterangkan dan diungkap oleh katakata belaka. Manusia yang mengalami satori setelah melalui latihan-latihan zen, hanya bisa mengalami suatu perubahan dalam dirinya. Ia memandang dunia dan sekelilingnya dengan lebih lapang, apa adanya, dan merasa dirinya dilahirkan kembali dengan pribadi baru.
\end{abstract}

Kata kunci: Zen Buddhisme, Pencerahan

\section{PENDAHULUAN}

Sejarah awal berdirinya agama Buddha diawali dengan kisah kepergian Sidharta Gautama dari istana keluarga Sakya. Siddharta meninggalkan segala bentuk kemewahan serta kenikmatan hidup duniawi dan membawa dirinya pada perjalanan menuju pencerahan. Dalam usia yang relative muda, ia mencari "arti hidup" dengan berkelana dan berguru pada orang-orang pintar yang dijumpai.

Dalam usaha mencari "arti hidup" pertamatama diawalinya dengan mencari dua orang guru Hindu terkemuka untuk mencari pikiran mereka tentang kebijaksanaan tradisi Hindu.
Kedua, Siddharta bergabung dengan sekelompok pertapa dan mencoba mengalami kehidupan mereka secara langsung. Ketiga, setelah meninggalkan kehidupan pertapaan dicobanya menggabungkan pikiran yang tegar dengan konsentrasi mistik menurut petunjuk raja-yoga. Setelah mengakhiri cara ketiga Sidharta menjadi Sang Buddha. Siddharta lahir kembali sebagai orang yang mendapatkan pencerahan rohani. Pencerahan didapat Siddharta setelah berhasil mengatasi penderitaan di sekitar kehidupan dan kematian.

Pencerahan bagi para penganut agama Buddha bukan sesuatu yang asing atau jauh dari pengalaman hidup manusia sehari-hari. Falsa- 
fah Buddhis menggambarkan hidup manusia yang menguasai alam semesta di dalam kehidupan. Menguasai alam semesta disebut dengan menguasai "Sepuluh Alam Hidup" (Jepang: jikkai), yang meliputi: (1) Neraka, (2) Kelobaan atau Kelaparan, (3) Kebinatangan, (4) Amarah, (5) Ketentraman atau Kemanusiaan, (6) Kebahagiaan atau Suka Cita, (7) Kecendekiaan atau Kesarjanaan, (8) Penciptaan, (9) Boddhisattva, (10) ke-Buddha-an. Masing-masing alam mengandung Sembilan alam lain, dan semuanya berjumlah seratus alam. Keseluruhan alam hidup tersebut diberi kualifikasi tiga gagasan (Jepang: sansaken), meliputi gagasan yang berhubungan dengan sifat jasmani sebagai manifestasi hidup. Perbedaan manifestasi hidup disebabkan oleh perbedaan individu dan tempat terjadinya manifestasi. Ini memberi jumlah keseluruhan menjadi "tiga ribu" (Jepang: zansen), hadir secara simultan dalam satu saat hidup (Jepang: I ichinen). Burton Watson menterjemahkan sebagai "tiga ribu gagasan dalam satu saat hidup" (Ikeda, 1986: 170).

Mendapatkan pencerahan menunjukkan kekuatan seseorang yang menguasai "Sepuluh Alam Hidup" dan hadir secara simultan dalam satu saat hidup. Pencerahan yang dicapai Siddharta merupakan respons timbal balik yang terjadi antara alam kebuddhaan yang ada di dalam alam semesta dan alam kebuddhaan yang melekat pada hidup Siddharta.

Siddharta setelah menjadi Sang Buddha mulai menyebarkan agamanya dan mendapat banyak pengikut. Pengikut-pengikut ajaran Buddha tersebar luas hingga menyeberang jauh sampai ke dataran Cina yang meliputi Tiongkok, Mongolia, Tibet dan Jepang. Seiring dengan penyebaran yang pesat, perkembangan agama Buddha di India terpecah menjadi dua aliran. Kedua aliran tersebut adalah Hinayana atau Theravada dan Mahayana. Aliran Hinayana bersatu dalam tradisi tunggal dan utuh. Ciri khas ajaran Buddha yang asli tampak pada aliran Hinayana di India. Ini berbeda dengan aliran Mahayana yang terus menerus terpecah dalam berbagai macam bentuk dan corak. Aliran Mahayana lebih berkembang pesat dan mudah tersebar luas dibandingkan Hinayana. Aliran ini cenderung lebih liberal dan mudah menyesuaikan dengan lingkungannya yang baru.

Salah satu bentuk aliran Mahayana yang berkembang dan menemukan tempatnya yang tepat di Jepang adalah zen. Zen merupakan salah satu hasil pemikiran Cina setelah bertemu dengan pemikiran India. Kata zen adalah logat Jepang yang berasal dari perkataan Cina ch'an dan merupakan terjemahan lebih lanjut bahasa Sanskerta dhyana. Dalam bahasa Jepang disebut sebagai zenna. Istilah tersebut berarti meditasi yang menghasilkan wawasan mendalam (Mudji Sutrisno, 1984: 9).

Ajaran-ajaran Zen yang berkembang di Jepang saat ini banyak dikenalkan oleh Daisetz Teitaro Suzuki. Ia adalah penyambung lidah Zen hingga ajarna-ajaran Zen banyak dikenal di kalangan pemikir barat. Tulisan-tulisannya banyak dibaca oleh pemikir-pemikir barat, bahkan memberi pengaruh dalam pola pikir mereka setelah bersinggungan dengan zen Buddhisme Jepang. Pemikir barat seperti Heidegger, Erich Fromm, Hubert Benoit, penulis Aldous Huxley dan para seniman Jerman yang tergabung dalam Die Zen Gruppe menaruh minat terhadap ajaranajaran zen. Zen bagi mereka dianggap tidak semata-mata sebagai suatu agama atau kepercayaan untuk memperoleh pengalaman rohani melalui meditasi. Keseimbangan fungsi tubuh dan jiwa dalam kerja maupun meditasi dipandang secara harmonis.

Menurut pandangan umum ajaran-ajaran zen tampak absurd. Pandangan ini tidak seluruhnya benar. Di balik absurditas, ajaran zen menyimpan segi praktis dan kedekatan dengan aktivitas sehari-hari. Zen dapat dipandang kosong tetapi sekaligus berisi. Pada tema ini, zen tidak melawan kontradiksi-kontradiksi logis seperti menyatakan "ya" dan "tidak" pada saat yang bersamaan. Bagi penganut zen, akal manusia tidak mampu mengatasi kontradiksi-kontradiksi itu. Selama akal masih ikut serta, manusia tidak akan pernah menemukan esensi zen. Kontradiksi-kontradiksi logis tidak menjadi pokok permasalahan yang harus dipahami zen buddhisme.

Dalam Zen Buddhisme dikenal istilah satori, yang dianggap sebagai esensi zen. Satori bagi para penganut zen hanya dapat dipahami melalui pengalaman langsung. Tanpa pengalaman ini orang tak akan tahu sepenuhnya apa itu zen. Dalam pengertian orang Jepang, satori diipahami pula sebagai ajaran tentang pencerahan atau penerangan. Pencapaian pencerahan adalah pencapaian seperti yang dilalui oleh Sang Buddha Gautama. Oleh kebanyakan orang, pencapa- 
ian pencerahan atau satori dalam zen sering dianggap unik dan aneh. Pengalaman mencapai pencerahan dipercaya sebagai hal yang tidak dapat diterangkan dan diungkap oleh kata-kata belaka. Manusia yang mengalami satori setelah melalui latihan-latihan zen, hanya bisa mengalami suatu perubahan dalam dirinya. Ia memandang dunia dan sekelilingnya dengan lebih lapang, apa adanya, dan merasa dirinya dilahirkan kembali dengan pribadi baru.

Permasalahan yang muncul jika dilihat dari pandangan umum adalah bagaimana menterjemahkan satori dalam pengertia logis, sebagai upaya berkomunikasi dengan orang-orang yang berminat terhadap zen. Zen Buddhisme harus dapat memberikan gambaran yang jelas proses diperolehnya satori dengan memberikan penuturan-penuturan yang paling tidak dapat dipercaya oleh para peminatnya. Kesulitan ini akan berakibat buruk jika para penganut Zen sendiri benar-benar mengambil jarak terhadap realitas yang dianggapnya sebagai tidak masuk akal dan tidak berguna. Bagaimanapun zen harus benarbenar menyentuh realitas dan tidak membatasi ajaran-ajarannya dalam kerangka yang diciptakannya sendiri.

DT Suzuki sebagai salah seorang penganut zen aliran Rinzai mencoba menjembatani ajaran-ajaran zen dengan realitas konkret terutama melalui tulisan, naskah atau pencerahan sebagai esensi zen belum banyak dikumpulkan dalam satu tulisan yang khusus dan utuh. Penjelasan yang diberikan pada literatur-literatur zen berkisar pada berjalannya proses latihan-latihannya. Belum banyak yang mencoba menggambarkan perolehan satori dan perwujudannya secara lebih sederhana namun ilmiah. Sejauh ini, satori atau pencerahan dianggap sebagai satu batu loncatan kecil yang tidak pernah berhenti menuju batu yang lain untuk mendapatkan satori yang baru.

\section{Landasan Teori}

1. Dua modus eksistensi manusia: "memiliki" dan "menjadi" merupakan dua modus pengalaman mendasar, kekuatan masingmasing menentukan perbedaan antara watak-watak individu dan berbagai tipe watak sosial (Fromm, 1987: 4).

2. Sifat dasar manusia merupakan bentuk personalitas individu yang ditentukan oleh kekhasan eksistensi manusia yang umum berlaku bagi semua manusia (Fromm, 1947: 13). Kemunculan akal menciptakan dikotomi-dikotomi, historikal dan eksistensial. Menyelesaikan dikotomi ini melalui: menghalangi kebenaran, mengakui kesendirian dan kesepian fundamentalnya (Fromm, 1947: 35-38).

\section{Metode Penelitian}

1. Interpretasi

Metode ini berkaitan dengan usaha untuk mendapatkan gambaran sejelas-jelasnya tentang teks, konsep atau ajaran zen yang akan dibahas. Melalui interpretasi ini, ajaran pencerahan diharapkan menjadi lebih jelas dan logis jika dibandingkan dengan penjelasan penganut zen yang menerimanya sebagai iman.

\section{Koherensi intern}

Masing-masing pemikiran dalam suatu tema senantiasa terkait satu sama lain. Hubungan antara satu tema dengan tema yang lain diciptakan secara logis dan sistematis, sehingga terjalin kesinambungan pemikiran pada setiap maksud dan pemikiran yang terkandung didalamnya.

3. Deskripsi

Memberi penjelasan terhadap tema yang diacu secara menyeluruh. Tema dilihat dari sudut pandang penjelasan tokoh atau aliran yang relevan dan sedapat mungkin mengikuti alur pemikiran sumber-sumber yang menjadi acuan. Selanjutnya memberikan penjelasan secara umum dan teratur berdasar tema yang menjadi bahan kajian.

4. Komparasi

Membandingkan pandangan dari tokoh atau aliran sesuai dengan tema yang dikaji. Perbandingan ini lebih ditujukan sebagai batu loncatan, selintas dalam usaha memberikan pemahaman pada tema agar menjadi jelas.

5. Bahasa Inklusif

Peneliti secara terbatas mengikuti pemakaian bahasa pada tema yang diambil untuk lebih menghidupkan suasana jaman secara temporer. Di sisi lain, pemakaian bahasa penulis ditujukan sedapat mungkin untuk memberikan pemahaman secara utuh tanpa meninggalkan arti yang jauh pada tema yang diambil sesuai dengan tokoh atau aliran yang dirujuk. 


\section{PEMBAHASAN}

Orang yang baru mengenal zen seakan-akan menyaksikan dunia yang ajaib, jungkir balik dan terasa sebagai hidup yang penuh kegilaan. Zen merupakan suatu ajaran yang penuh dengan dialog membingungkan serta paradoksal-paradoksal (Smith, 1985: 165). Dialog dan paradoksal-paradoksal tampak jelas pada dialog koan, yang digunakan sebagai sarana mencapai pencerahan zen pada aliran rinzai.

Zen yang berkembang di Jepang terbagi dalam aliran Sato Zen dan Rinzai Zen. Aliran ini muncul karena adanya perbedaan tafsir terhadap inti pokok ajaran pencerahan. Aliran Sato mengembangkan ajaran pencerahan yang hening. Pencerahan muncul sebagai kegiatan naluriah yang membiaskan dan memantulkan cahaya pancaran budi yang b erdasar pada kodrat Buddha. Ciri aliran Soto ialah tenang, menekankan kerja dalam keheningan serta "kepatuhan" (passivity). Metode satu-satunya untuk mencapai penerangan melalui za-zen, sebuah meditasi dalam posisi duduk bersila. Pada aliran rinzai berusaha mencapai penerangan cara koan dan mondo. Koan dan mondo merupakan hasil sistematisasi dalam usaha untuk mencapai penerangan secara aktif. Aliran rinzai ini bersifat lebih dinamis dan aktif bila dibanding dengan aliran Soto (Mudji Sutrisno, 1984: 14).

Bertanya tentang zen, apakah ia merupakan suatu sistem filsafat, akan sangat diberikan jawaban. Zen bukan suatu sistem yang berdasarkan atas logika dan analisa. Metode latihan zen sering dianggap tidak ilmiah dan absurd. Diperlukan suatu bentuk latihan dan praktek selama bertahun-tahun untuk memahami dan mencapai tujuan pelajaran zen.

Memahami zen dilakukan dengan suatu cara meditasi atau Samadhi. Kunci latihan ini terletak pada penyadaran yang meletakkan konsentrasi pada 'luar' tubuh. Satu hal yang harus dihindari adalah 'berpikir'. Seseorang harus meniadakan pikiran untuk bermeditasi atau bersemadhi (Verhaar, 1989: 135). Pada pengertian ini, amat sulit untuk menganggap zen sebagai suatu filsafat dalam pengertian secara umum, karena ia telah membentangkan tembok 'anti berpikir', 'anti logika'.

Zen menandang akal dari dua segi: pertama, logika dan penjelasan zen hanya dapat dimengerti dari sudut tinjauan pengalaman yang secara mendasar berbeda dari pengalaman biasa. Kedua, para guru besar zen bertekad agar para siswanya benar-benar memperoleh pengalaman secara langsung dan bukannya diganti dengan kata-kata belaka (Smith, 1985: 170).

Penalaran logis sangat dihindari zen karena satu alasan khusus, yaitu penalaran logis memasukkan orang ke dalam kerangka berpikir dalam kedudukan subjek dan objek. Jika cara demikian ditempuh, maka semakin menjauhkan manusia dari pemahamannya, maka semakin menjauhkan manusia dari pemahamannya tentang kedudukan dirinya. Manusia akan tenggelam dalam dualisme kategori rohani dan jasmani, yaitu pencipta dan yang diciptakan. Zen mengajak manusia untuk melihat objek dengan masuk ke dalam objek itu sendiri (Mudji Sutrisno, 1984: 17). Melihat dari dalam hanya mungkin dicapai dalam proses "menjadi" atau proses kesatuan subjek dan objek. Pada proses 'menjadi' saat subjek dan objek terlebur, kesadaran itu harus dibangkitkan untuk memperoleh pencerahan.

Epistemologi manusia berkaitan dengan dualisme subjek dan objek dalam Zen Buddhisme terletak pada fungsi prajna dan vijnana. Vijnana berfungsi membagi realitas secara praktis. Realitas dipandang dalam dualisme subjek dan objek. Untuk memahami adanya satori harus disadari adanya prajna, yaitu epistemologi manusia yang tidak membagi-bagi realitas dalam dualis. Dalam prajna, subjek dan objek adalah sama. Prajna membagi diri dalam subjek dan objek, namun juga berdiri sendiri, menjadi absolut dalam totalitasnya. Penyair atau para seniman Zen memandang peristiwa ini sebagai satori atau mendapatkan pencerahan. Pertama, terdapat sesuatu yang tidak membagi diri dalam subjek dan objek. Sesuatu itu adalah kesatuan sebagaimana adanya. Kedua, sesuatu menjadi sadar akan dirinya, membagi diri dalam subjek dan objek, yang oleh para seniman dicontohkan seperti bunga dan penyair. Menjadi sadar, adalah membagi. Seorang penyair dan bunga saling melihat. Relasi demikian akan disadarkan dengan satori (Suzuki, 1969: 24-26). Seorang penyair melihat bunga, bunga itu tidak lain adalah diri penyair. Seorang penyair, hidup dalam bunga. Tidak ada lagi penyair dan bunga, karena keduanya melebur. Tidak ada lagi subjek dan objek karena keduanya adalah satu.

Seorang penganut Zen dianggap mencapai 
satori jika ia mencapai pencerahan untuk melihat inti kodrat diri seseorang atau sesuatu realitas. DT Suzuki menulis bahwa inti kodrat diri bukan suatu entitas atau kenyataan yang dimiliki seseorang sebagaimana dipahami oleh akal. Satori mengatasi akal, satu pikiran mutlak, kekinian mutlak, kemurnian yang benar-benar, kekosongan dan apa adanya (Mudji Sutrisno, 1984: 15). Pencapaian ini kadang merupakan proses yang panjang. Meditasi atau Samadhi bisa dilakukan berhari-hari, berbulan-bulan, bahkan bertahun-tahun. Proses yang panjang ini menghasilkan satori yang muncul hanya sebagai kilatan lampu. Satori datang hanya sekejap, namun mampu merubah semua realitas di sekelilingnya.

Dalam pengalaman Zen, yang lebih penting adalah kesatuan pada yang dianggap berada di luar si pemeditasi. Kesatuan itulah yang mendasari latihan meditasi. Dalam kesatuan kekosongan akan nampak penuh, hal biasa menjadi indah. Sang Buddha merumuskan pengalaman ini sebagai pengalaman realitas yang tidak lain adalah pengalaman tubuh. Lebih jauh lagi melalui Samadhi yang dijalaninya akan tiba saat pencerahan, yang di dalam Zen disebut satori. Satori melampaui kemungkinan dari segala pengetahuan yang tertinggi (Verhaar, 1989: 136).

Meditasi atau Samadhi dilakukan dengan sarana za-zen. Za-zen adalah sebutan Zen untuk meditasi atau Samadhi. Pai-chang adalah penemu Zen di Cina, yang menulis tentang latihan Zen dalam petunjuk-petunjuk untuk melaksanakan meditasi ruang (Suzuki, 1973: 327). Dalam za-zen perlu dibangkitkan kesadaran penuh terhadap diri. Diadakan pemutusan hubungan dengan hal-hal di luar diri secara fisik dan melakukan pengheningan diri dalam ruang yang tenang.

Sarana yang digunakan untuk menyempurnakan za-zen adalah koan. Koan adalah suatu bentuk teka-teki atau tanya jawab yang hasilnya dapat meruntuhkan tatanan logika yang dipercayainya. Pandangan yang lebih keras menyatakan bahwa melalui koan, zen berusaha menghindari penggunaan akal manusia. Melalui koan, Zen menggerakkan ketidaksabaran pikiran manusia dan akan menemukan jalan buntu untuk menjawab teka-teki yang tampak pada jawaban. Koan menjadi semacam alarm yang membangun pikiran yang tertidur. Pada latihan yang lain koan lebih berfungsi untuk menghan- curkan dualisme budi dan untuk menguji kemurnian pencerahan seorang murid. Studi tentang koan dan za-zen dalam zen buddhisme tidak dapat dilepaskan satu sama lain. Koan dan za-zen adalah dua bentuk latihan yang saling melengkapi. Koan adalah mata dan za-zen kaki dalam mempelajari zen buddhisme (Suzuki, 1969: 103).

Fungsi koan bagi penganut Zen dewasa ini, cenderung sebagai "starter", yang memberikan suatu tanda peralihan untuk memacu diperolehnya pengalaman Zen. Dalam keadaan yang memungkinkan untuk menangkap kesadaran, pikiran terbuka bagi berkembangnya suatu satori.

Contoh tanya jawab koan, seperti banyak ditemukan dalam literatur-literatur zen, diantaranya sebagai berikut:

Apakah seekor anjing memiliki kodrat Buddha?

Sang pendeta Zen berkata "Mu!" (tidak)"

Sebuah tangan tidak bisa bertepuk kemudian,

Bagaimana bunyi tepuk sebuah tangan

Dapatkah anda mendengar tanpa membuat keributan?

Dapatkah anda mendengan objek tanpa memukulnya?

Dapatkah anda mendapatkan pengetahuan tentang kenyataan kodrat diri anda? Betapa tolol pertanyaan itu !

(Watts, 1976 : 185).

Bagaimana tampaknya wajahmu sewaktu nenek moyangmu belum lahir?

Dahulu kala seseorang memelihara itik dalam sebuah botol. Itik itu tumbuh semakin besar, hingga ia tidak dapat lagi keluar dari botol. Namun orang itu tidak mau memecahkan botol tersebut, juga ia tidak ingin menyakiti itik itu. Bagaimana cara anda mengeluarkannya ? Sang guru besar berteriak, Hai pejabat pemerintah ! ... Ya demikian pejabat itu menjawab, nah itik telah keluar!

(Smith, 1985: 172).

Koan pada contoh di atas terlihat tidak logis. Dipandang tidak logis karena akal berfungsi dalam kerangka yang diciptakannya sendiri. Akal manusia membentuk kerangka yang berstruktur. Koan sebagai pertanyaan dan jawaban 
memiliki logika sendiri, yang bersifat keras dan transcendental (Smith, 1985: 174). Pemecahan jawaban koan bukan pada penalaran logis namun berdasar tema dan permasalahan yang dimunculkan yang diterima secara apa adanya (Suzuki, 1973: 333).

Hampir serupa dengan koan sebagai sarana untuk memperoleh pencerahan, digunakan pula sarana mondo. Arti harafiahnya adalah tanya jawab. Mondo adalah dialog antara dua orang, biasanya antara guru dan murid. Dialog dalam mondo, berbeda dengan Plato Dialogues atau Buddha Dialogues yang merupakan rentetan tanya jawab yang berhubungan. Dialog mondo berlangsung pendek, kasar dan tidak urut (Suzuki, 1970: 28).

Mondo berfungsi untuk menunjuk ada dan tidaknya pengalaman satori,. Dalam Zen Buddhisme koan dan mondo diletakkan bersama-sama sebagai sarana yang paling penting untuk mencapai satori. Fungsi sebenarnya koan dan mondo adalah pertama koan digunakan untuk mengontrol kegiatan budi manusia. Koan membiarkan murid dengan akal budinya mengalami sendiri batas-batas kemampuan inteleknya. Maksud menunjukkan arah ini agar seorang murid memahami bahwa ada bidang lain dimana akal manusia tidak mampu menerobos. Kedua, koan dan mondo berperan membantu untuk menguji kematangan penerangan. Diharapkan bahwa satori atau mendapatkan pencerahan sebagai buahnya akan muncul secara murni. Pada fungsi pertama ditekankan pada usaha mencari sedang pada fungsi kedua adalah mematahkan kecenderungan berpikir. Seorang murid lebih memantapkan pengalaman pencerahan dengan cara mengujinya sampai ke inti kemurnian pencerahannya (Mudji Sutrisno, 1984: 19).

Mencapai satori bagi para penganut zen merupakan tujuan sekaligus awal dimulainya pengalaman zen. Sebagai tujuan, pencerahan bukanlah tujuan tertinggi. Tujuan pencerahan merupakan proses yang panjang dan tak akan berakhir. Semakin banyak ia mendapaktan satori atau pencerahan, semakin ia harus banyak mengulang. Semakin jelas pemahaman, semakin banyak yang harus dipelajari.

Menurut Suzuki, terdapat dua cara umum dalam Zen Buddhisme untuk menyadari adanya pencerahan. Pertama, melalui cara verbal dan kedua aksional. Cara pertama, berpijak dari pandangna umum, bahwa umat manusia mem- butuhkan bahasa, sebagai sarana komunikasi dalam kehidupan kelompok. Dicontohkan oleh Suzuki, tentang cinta. Cinta adalah esensi kemanusiaan, cinta membutuhkan sesuatu nuntuk mengangkat harkat diri. Umat manusia harus hidup berdampingan untuk mencapai kehidupan saling mencintai. Cinta memerlukan suatu alat komunikasi, yaitu bahasa. Demikian pula dengan zen yang merupakan pengalaman umat manusia yang terpenting, seseorang harus menggunakan bahasa untuk mengekspresikan pada individu lain seperti juga berkomunikasi dengan diri sendiri. Terutama dalam zen verbal, cara ini memiliki gambaran tersendiri yang mencampuradukkan aturan pengetahuan bahasa. Dalam zen pengalaman dan ekspresi adalah satu. Zen verbalisme menekankan pengalaman paling konkret (Suzuki, 1988: 7).

Contoh bentuk verbal ini adalah ketika seorang guru zen ditanya tentang apa itu kebijaksanaan, apa itu hidup, hanya dijawab "bersihkan tanganmu”, cucilah mangkok tempat kamu makan. Jawaban ini bagi zen bukan tanpa alasan. Hidup, selalu dekat dengan masalah-masalah praktis dan konkret. Manusia jarang menghayati aktivitas-aktivitas konkretnya. Manusia bekerja dan melakukan kegiatan terjebak dalam rutinitas. Bagaimana mereka memahami hidup, mengetahui tentang kebijaksanaan, sedangkan mereka tidak dapat memberi makna pada kegiatan atau aktivitas sehari-hari seperti mencuci tangan dan mencuci mangkok (Suzuki, 1988: 7).

Di sisi lain jawaban-jawaban, ekspresi seseorang yang memperjelas komunikasi, adalah bahasa yang didasarkan pada realitas konkret. Bahasa dan pengalaman tidak berbeda, namun terdapat batasan-batasan bahasa dalam menterjemahkan realitas. Keterbatasan pengalaman individu dalam memahami bahasa harus dialami secara personal, dan bukan melalui penjelasan dan pemahaman orang lain. Contoh lain pemahaman verbal jika kita memperhatikan puisi-puisi zen. Bentuk posisi haiku atau hokku ini dibuat oleh Baso. Sejak ini hanya terdiri dari 17 suku kata, yaitu sebuah sajak singkat tetapi mampu menggambarkan suasana paling konkret. Tampak mustahil jika seorang penyair pada umumnya menggambarkan musim bunga hanya dengan 17 suku kata. Penyair mengajak pembaca untuk mengalami secara langsung dilakukan dengan menciptakan sendiri suasana musim bunga. Melalui puisi ini pembaca tidak 
digiring dengan kata-kata penyair (de Martinio, 1963: 1).

Pendekatan kedua dilakukan secara aksional. Dalam pendekatan secara aksional ini, apa yang kita sebut tubuh dilibatkan. Dikisahkan pada saat Rinzai ditanya apa hakikat ajaran Buddha, Rinzai segera beranjak dari tempat duduknya, memegang jubah penanya, kemudian menampar muaknya dan berlalu. Sang penanya masih berdiri di tempatnya, terkesima. Orang di sebelahnya menegur penanya tersebut, mengapa anda tidak menunduk". Penanya sadar dari lamunannya, dan saat ia menundukkan kepala memberi hormat kepada sang guru, sesungguhnya ia telah mendapatkan satori. Kisah yang serupa ketika Baso berjalan-jalan bersama Hyakujo (Pai-chang) memperhatikan sekumpulan angsa liar terbang. Baso bertanya kepada Hyakujo, kemana mereka terbang ? Hyakujo menjawab "mereka sudah terbang jauh" (lenyap). Baso menoleh, dan memegang hidung Hyakujo dan melintirnya hingga ia merasa kesakitan. Siapa bilang angsa-angsa liar itu lenyap ? Jawab Baso kasar. Ini membuat Hyakujo sadar bahwa sang guru tidak berbicara tentang konsep-konsep angsa liar yang menghilang di balik awan. Sang guru bermaksud menarik perhatian Hyakujo pada kehidupan angsa-angsa liar yang terus terbang dengan diri Hyakujo sendiri. Maksudnya adalah menjadikan dirinya sebagai bagian dari angsa liar itu (Suzuki, 1988: 8).

Manusia mendapatkan satori bukan didorong oleh kekuatan yang berada di luar dirinya. Satori melekat dalam diri manusia secara individual yang mempunyai relasi dengan alam. Manusia memperoleh pencerahan sebagai pengalaman yang bersifat khusus. Manusia sebagai pribadi, memegang peranan dalam diri. Sifat khusus yang melekat ini menjelma secara personal dalam proses kesatuan antara dunia di dalam dirinya dan realitas di luar dirinya.

Seperti aliran-aliran agama Buddha, Zen Buddhisme juga menekankan pada an-atta (tiadanya aku). Pada prinsip an-atta bukan berarti mutlak mengingkari adanya aku. Prinsip ini hanya menyatakan bahwa aku tidak pernah dapat menjadi dasar untuk identitas atau satori (Verhaar, 1989: 137). Manusia menjadi manusia tidak dengan meletakkan aku sebagai diri disbanding dengan aku-aku yang lain. Manusia sebagai manusia bukan pada kesadaran terhadap identitas dirinya. Manusia sebagai manusia, sep- erti pendapat Verhaar tentang Zen Buddhisme, adalah penyadaran (awareness) yang mengakibatkan manusia bersatu dengan apa yang disadarinya.

Kebersatuan manusia dengan yang disadarinya muncul dalam suatu tindakan menjadi. Menjadi sebagai suatu proses kesatuan, adalah proses yang tidak memisahkan manusia dengan realitas dan alam.

Dalam pemikiran Erich Fromm, disebut manusia yang menjadi adalah ideal bagi modus eksistensi manusia. Modus menjadi ini dibedakan dengan modus memiliki. Kedua modus eksitensi manusia ini melekat sebagai dualisme kodrati yang masih mungkin diarahkan kembali pada ideal tunggal menjadi (Fromm, 1987: 100).

Penyadaran dapat dikatakan sebagai menjadi pada saat apa yang disadarinya menyatu dalam dirinya. Hal serupa terjadi pada saat Baso menegur Hyakujo dalam kisah angsa-angsa liar yang terbang di awan dan dianggapnya telah lenyap. Memperoleh satori tidak lain memperoleh penyadaran seperti sang Buddha yang dicerahkan, dibangunkan dari kesadaran dirinya sebagai manusia. Pada kondisi ini aku dalam diri telah hilang. Aku tidak lain dari engkau, tempat aku tinggal, bunga-bunga, angsa-angsa liar di awan.

\section{PENUTUP}

Setelah memperhatikan pemikiran Zen Buddhisme uraian sebelumnya, berikut ini akan ditinjau kembali pokok-pokok pemikiran zen sebagai kesimpulan akhir.

Pertama: metode untuk memahami ajaran Zen Budhisme adalah metode meta-ilmiah (antisciencetific). Metode ini berbeda dengan metode sintesa dan analisa yang digunakan dalam ilmu pengetahuan empiris. Metode matailmiah merupakan metode yang tidak membedakan antara subjek dan objek, atau pengamat dan yang diamati. Subjek dan objek tidak berbeda, masing-masing berdiri sendiri sekaligus menegaskan keberadaan diri dalam kesatuan. Melalui metode meta-ilmiah akan didapat pengetahuan intuitif yang menghindari pemikiranpemikiran logis.

Kedua: pengalaman memperoleh satori atau pencerahan adalah mutlak diperlukan untuk memulai pelajaran dan memasuki kehidupan zen. Mendapatkan pencerahan atau satori bu- 
kan sebagai akhir dari tujuan pelajaran zen. Pencerahan atau satori adalah bentuk pengalaman konkret yang bersifat khusus, yang dapat diraih manusia untuk mengatasi dan memandang permasalahan di sekitar manusia secara lebih baik dan benar. Memperoleh satori atau pencerahan untuk pertama kali adalah awal untuk memperoleh satori atau pencerahan berikutnya. Pengalaman ini terus berlangsung tanpa henti hingga dicapai pencerahan atau satori total seperti diperoleh oleh Sang Buddha.

Ketiga: alat atau sarana pertama untuk memperoleh pencerahan adalah za-zen. Za-zen merupakan sikap duduk Samadhi zen yang berfungsi untuk melihat realitas secara intuitif. Realitas dipandang apa adanya (suchness : see just as it is) dan dibiarkan mengungkapkan dirinya sendiri. Realitas dalam Zen Budhisme merupakan kenyataan konkret, yang meliputi alam atau kosmos dan segala sesuatu didalamnya, serta tindakan atau aktivitas manusia. Pemahaman kenyataan konkret melalui za-zen ini diiringi dengan menurunkan pikiran dan fungsi berpikirnya yang melihat realitas sebagai objek.

Keempat: alat atau sarana kedua untuk memperoleh pencerahan adalah koan dan mondo. Koan dan mondo merupakan bentuk pertanyaan-pertanyaan yang dilontarkan guru zen kepada murid-muridnya. Koan berfungsi sebagai cara untuk menurunkan pikiran. Mencari jawaban dari pertanyaan koan dilakukan dengan zazen. Jawaban dari koan dalam za-zen dihubungkan melalui tubuh manusia secara fisik. Hampir sama dengan koan, mondo adalah pertanyaan atau dialog yang akan menentukan pada ada dan tidaknya pengalaman satori atau pencerahan.

Kelima: pencerahan atau satori dalam zen merupakan suatu cara pandang baru seseorang terhadap realitas dan alam secara lebih baik dan apa adanya. Realitas dalam pandangan seseorang yang mendapatkan pencerahan tidak lain dari realitas diri. Diri yang sejati ditemukan dalam relasi antara manusia dan alam. Menemukan realasi yang harmonis antara manusia dan alam adalah dengan membuka intuisi manusia sehingga tercapai kesadaran tunggal.

Keenam: mencapai kesadaran tunggal adalah proses identifikasi manusia terhadap realitas di luar dirinya. Proses identifikasi tidak sematamata dilakukan dalam Samadhi, namun juga dalam aktivitas sehari-hari dalam bekerja. Men- gidentifikasi dengan realitas berarti menunjukkan diri pada pandangan realitas. Realitas memberi corak dan warna kepada manusia. Bentuk kesadaran ini bukan berarti melihat kesadaran di luar diri, melainkan melihat kesadaran sebagai suatu relasi yang utuh. Relasi ini tampak dalam cara pandang yang tidak lagi terjebak pada dualisme pikiran subjek dan objek atau pengamat dan yang diamati.

Ketujuh: menjadi dalam zen Buddhisme menunjuk pada penegasan keberadaan segala sesuatu. Menjadi adalah berada dan sebaliknya berada adalah menjadi. Istilah menjadi menunjuk pada eksistensi segala sesuatu yang terikat dalam ruang dan waktu yang khusus. Terletak dalam ruang khusus adalah bentuk kesadaran yang berada di dalam kekosongan secara intuitif. Terletak dalam waktu khusus adalah terletak di belakang waktu (beyond time, timelessness). Pengertian waktu khusus menunjukkan bahwa dicapainya pencerahan adalah setelah taraf kesadaran tunggal atau menjadi berlangsung secara cepat atau sekilas dan kemudian tidak muncul lagi. Peristiwa diperolehnya sangat cepat, tetapi akan merubah cara pandangnya terhadap realitas atau alam.

Kedelapan: Pencerahan yang dicapai seseorang merupakan taraf lebih lanjut dari menjadi. Seseorang yang menyadari bahwa realitas dan diri adalah selalu aktif akan disadarkan dari aktivitas identifikasi diri. Diantara proses identifikasi diri dan pandangan dualistis subjek dan objek terdapat pencerahan. Seseorang yang berada dalam taraf menjadi secara perlahan akan menyadari bahwa dirinya berbeda dengan sesuatu yang lain. Sesaat setelah mencapai taraf menjadi dan sebelum disadarkan pada cara pandang dualistis subjek dan objek di sanalah seseorang mendapatkan pencerahan. Dicapainya pencerahan oleh seseorang akan mempengaruhi cara pandangnya terhadap realitas dan segala sesuatu di dalamnya.

Kesembilan: seseorang yang memperoleh pencerahan tidak dapat mengemukakan dan menunjukkan pada orang lain. Ia tidak dapat pula menghitung berapa banyak pencerahan yang telah didapat dan kemudian berhenti karena telah berhasil mendapatkannya. Memperoleh pencerahan selalu berlanjut pada upaya untuk memperoleh pencerahan-pencerahan yang lain. Seiring dengan kesadaran manusia dan realitas yang selalu aktif dan menjadi, maka mendapat- 
kan pencerahan tidak dapat berhenti. Pencerahan atau satori sebagai cara pandang terhadap realitas selalu berjalan dalam kesadaran diri secara terus menerus hingga ia mengatasi taraf yang tak terhingga dan terbatas.

Kesepuluh: mendapatkan pencerahan adalah bentuk pengalaman personal yang hanya bisa dipahami dengan menjalaninya sendiri. Perwujudan seseorang yang telah meraih pengalaman personal ini tampak pada sikap dan pandangan hidupnya. Perwujudan pencerahan secara terbatas adalah dalam karya seni khas zen. Dalam tingkah laku akan tampak dalam suatu tindakan bebas. Kebebasan ditunjukkan melalui tindakan spontan, wajar atau tidak dibuat-buat. Orang lain tidak dapat memahami bentuk pencerahan ini kecuali ia membuka ruang kesadaran baru dalam dirinya secar intuitif.

\section{DAFTAR PUSTAKA}

Bakker, Anton, 1990, Metodologi Penelitian Filsafat, Penerbit Kanisius, Yogyakarta.

Caligiuri, Angelo M, 1966, The Concept of Freedom in The Writings of Erich Fromm : An Exposition and Evaluation, Pontificia Universitas Gregoriana Facultas Philosophical, Roma.

Capra, Fritjof, 1983, The Tao of Physics, Bantam Books, New York.

Creel, HG, 1989, Alam Pikiran Cina - Sejak Confucius sampai Mao Zedong, terjemahan : Soejono Soemargono, Tiara Wacana, Yogyakarta.

de Martino, Richard (ed), 1963, Zen Buddhism and Psychoanalysis, $1^{\text {st }}$ Evergreen Editor, New York. de Barry, William Theodore, 1969, The Buddhist Traditional in India, China and Japan, Vintage Books, New York.

Fromm, Erich, 1941, Escape From Freedom, Rinehart and Company, New York.

Fromm, Erich, 1947, Man for Himself, Rinehart and Company, New York.

Fromm, Erich, 1987, Memiliki dan Menjadi, Terjemahan : F. Soesilohardo, LP3ES, Jakarta.

Fromm, Erich, 1963, Psychoanalysis and Zen Buddhism, dalam Richard de Martino (ed), Zen Buddhism and Psychoanalysis, $1^{\text {st }}$ Evergreen Editor, New York.

Hartoyo Andangjaya, 1991, Dari Sunyi ke Bunyi - Kumpulan Esai Tentang Puisi, Grafiti, Jakarta.

Harun Hadiwijono, 1985, Sari Filsafat India, BPK Gunung Mulia, Jakarta.

Humpreys, Christmas, 1952, Buddhism, Penguin Books Ltd, Harmondsworth, Middlesex.

Ikeda, Daisaku, 1989, Sang Buddha Shakyamuni, Terjemahan : Anton Adiwijoto, Sakyamuni, PT. Indira, Jakarta.

Kyokai, Bukkyo Dendo, 1966, The Teaching of Buddha, Buddhist Promoting Foundation - Kosaido Printing Co, Tokyo.

Leahy, Louis, 1984, Manusia Sebuah Misteri : Sintesa Filosofis tentang Makhluk Paradoksal, PT. Gramedia, Jakarta.

Mardi Prasetya, 1993, Manusia dan Alamnya Dalam Buddhisme Zen, dalam Jelajah Hakikat Pemikiran Timur, Seri Filsafat Driyarkara : 4, Capita Selecta, PT. Gramedia Pustaka Utama, Jakarta.

Mudji Sutrisno, 1984, Zen dan Fransiskus, Penerbit Yayasan Kanisius, Yogyakarta.

Mudji Sutrisno, 1993, Kata Pengantar, dalam Jelajah Hakikat Pemikiran Timur, Seri Filsafat Driyarkara : 4, Capita Selecta, PT. Gramedia Pustaka Utama, Jakarta.

Philips, B, 1975, The Essentials of Zen Buddhism - Selected from the writings of DT Suzuki, Greenword Press, New York.

Radhakrishnan, 1958, Indian Philosophy, volume II, The Macmillan Company, New York.

Richie, Donald, 1982, Zen Inklings, Weatherhill, New York.

Sastraptedja, 1981, Sejarah Filsafat India, STF Driyakara, Jakarta.

Smith, Huston, 1985, The Religions of Man, Terjemahan : Saafroedin Bahar, Yayasan Obor Indonesia, Jakarta. 
Suzuki, D.T, 1963, Lectures on Zen Buddhism, dalam Richard de Martino, Zen Buddhism and Psychoanalysis, $1^{\text {st }}$ Evergreen Editor, New York.

Suzuki, D.T, 1969, An Introduction to Zen Buddhism, Rider \& Company, London.

Suzuki, D.T, 1970, The Field of Zen, Harper \& Row Publishers Inc, New York.

Suzuki, D.T, 1973, Essays in Zen Buddhism, First Series, London.

Suzuki, D.T, 1988, Zen and Japanese Culture, Bolling en Found Inc, New York.

Titus, Harold H,. 1984, Persoalan-persoalan Filsafat, Terjemahan : HM Rasjidi, Bulan Bintang, Jakarta.

Watts, Allan W, 1976, The Way of Zen, Penguin Books Ltd, Harmondsworth, Middlesex.

Verhaar, John W.M, 1989, Identitas Manusia - Menurut Psikologi dan Psikiatri abad ke-20, Penerbit Kanisius, Yogyakarta. 